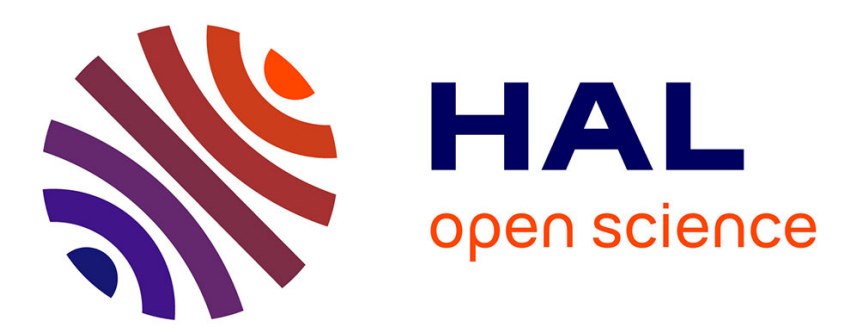

\title{
Direct Coupling of PEM Fuel Cell to Supercapacitors for Higher Durability and Better Energy Management
}

\author{
K. Gérardin, S. Raël, Caroline Bonnet, Divyesh Arora, François Lapicque
}

\section{To cite this version:}

K. Gérardin, S. Raël, Caroline Bonnet, Divyesh Arora, François Lapicque. Direct Coupling of PEM Fuel Cell to Supercapacitors for Higher Durability and Better Energy Management. Fuel Cells, 2018, 18 (3), pp.315 - 325. 10.1002/fuce.201700041 . hal-01817164

\section{HAL Id: hal-01817164 \\ https://hal.univ-lorraine.fr/hal-01817164}

Submitted on 24 Jul 2019

HAL is a multi-disciplinary open access archive for the deposit and dissemination of scientific research documents, whether they are published or not. The documents may come from teaching and research institutions in France or abroad, or from public or private research centers.
L'archive ouverte pluridisciplinaire HAL, est destinée au dépôt et à la diffusion de documents scientifiques de niveau recherche, publiés ou non, émanant des établissements d'enseignement et de recherche français ou étrangers, des laboratoires publics ou privés. 


\title{
Direct Coupling of PEM Fuel Cell to Supercapacitors for Higher Durability and Better Energy Management
}

\author{
K. Gérardin ${ }^{1}$, S. Raël ${ }^{2,1}$, C. Bonnet ${ }^{1 *}$, D. Arora ${ }^{2,1}$, and F. Lapicque ${ }^{1}$ \\ ${ }^{1}$ Laboratory for Reactions and Chemical Engineering, CNRS - Univ. Lorraine, BP 20451, F-54001 Nancy Cedex, \\ France \\ ${ }^{2}$ Research Group in Electrotechnics and Electronics in Nancy, Univ. Lorraine, Avenue de la Foret de Haye, F- \\ 54500 Vandoeuvre-lès-Nancy, France
}

Received

[*] Corresponding author, caroline.bonnet@univ-lorraine.fr

\begin{abstract}
A single polymer electrolyte fuel cell has been directly hybridized to a stack of three supercapacitors: the system formed has been investigated in operation in the Fuel Cell Dynamic Load Cycle, which emulates the energy demand in transported applications. Comparison with regular, non-hybridized fuel cell operation was analyzed in terms of hydrogen consumption in the case that the gas flow rates are directly controlled by cell current during the cycles with constant gas stoichiometric factors: the smoothening effect of the supercapacitors in the overall circuit leads to more even profiles of the cell current and voltage in the cycle, which allows safer and better hydrogen consumption management in this regime: the average $\mathrm{H}_{2}$ consumption per cycle could be reduced by $16 \%$ without change of the overall energy produced. Besides, the runs were conducted over more than 1300 hours with evaluation of the fuel cell performance and capacity at regular intervals, with or without hybridization. A moderate positive effect of hybridization was observed in the time variations of the voltage-current curves and the fuel crossover. However, the resistances for ohmic, charge transfer and diffusion phenomena, were not so much improved by the hybridization, in spite of less sharp voltage.
\end{abstract}

Keywords: Durability, Electrochemical Characterization, Energy Management, Hybridization, PEM fuel cell, Supercapacitor.

\section{Introduction}

As stated in [1], fuel cells $(F C)$ are one of the most promising technology in transport applications. Firstly, they are locally free of greenhouse gas emission, and more generally of polluting waste emission, so that they can be a solution to the problem of air pollution in big cities. In comparison with battery electrical vehicles, $F C$ present higher energy densities which enable a greater autonomy, and are not subjected to the charging problems encountered with battery technologies.

However, fuel cells are little adapted to sudden variations of current because of the appreciable response time of flow controllers [2], or of air compressor [3]. As a result, load peaks can generate a phenomenon known as air starvation, which is responsible of critical voltage drops. This induces stresses at the cell membrane electrode assembly (MEA), causing irreversible degradations [4], so that typical current profiles associated with urban cycles reduce significantly $F C$ lifetime. Besides, standard fuel cell systems include converters to raise the $F C$ voltage to the required level. Additionally, an inverter is usually integrated to the system for conversion to alternative current. The high frequency $(H F)$ and low frequency $(L F)$ current ripples generated by the presence of power electronic converters, can induce accelerated performance decrease $[5,6]$, degradation of the membrane electrode assembly $(M E A)[7,8,9]$, electrochemical active surface area $(E C S A)$ decrease [7], and gas diffusion layer $(G D L)$ degradation [10].

To mitigate the slow dynamics of $F C$ system, and the sensitivity of the cell components to power peaks, a widespread solution consists in coupling the FC to another power source, such as batteries or supercapacitors $(S C)$. The aim is to provide power peaks by means of the energy storage device, allowing slow regime variation for the $F C$, and in some cases, a decrease in the $F C$ rated power. Many applications for hybridized $F C$ systems can be found in the literature: military portable $[11,12]$ or transport [13] applications, vehicle applications $[14,15,16]$, tramway applications [17, 18], aircraft applications [19], and even stationary applications [20, 21].

Typical hybridization of a fuel cell to supercapacitors involves two DC/DC power electronic converters, the first one to boost the $F C$ voltage, and the second one to connect supercapacitors. The associated architectures and solutions clearly offer the best potentiality in term of energy management and $F C$ power control, because of the high degree of freedom provided by converters. Nevertheless, the presence of the various ancillary elements results in significant increase in volume, weight, cost and failure risk of the overall system, in addition to the energy losses 
caused. Besides, these topologies do not generally protect the $F C$ against $H F$ current ripples, except for specific and dedicated power electronic architectures.

A simple and efficient way to proceed to $F C$ hybridization consists in connecting directly the storage device, generally $S C$ but not only, to the $F C$. The so-called $F C$ direct (or passive) hybridization has been investigated in a couple of former works. In [11] and [12], a direct $F C$-SC system has been chosen for military portable applications, characterized by pulsed currents. The same kind of application is treated in [22], using a lead acid or nickelcadmium battery, instead of $S C$. The previously mentioned work [19] also deals with direct hybridization of a $F C$ with a battery, from lithium-ion technology. However, as it is often the case when batteries are used in combination with $F C$, the connection between the two power sources is not entirely direct, a battery charger is still needed to control and limit the current between the $F C$ and the battery. Wu et al. [23] presented the design and test results of a direct $F C$-SC hybrid source involving a $9.5 \mathrm{~kW} P E M F C$. It should be noticed here that the system was a standard $F C$ stack to $S C$ stack connection, with a resistive precharge device. On the contrary, a cell-to-cell direct hybridization of $F C$ and $S C$ has been considered [24] in particular, with investigation of current and power sharings during steps of power demand, depending on the $F C$-SC configuration.

Direct hybridization of $F C$ and $S C$ is to enable to prevent detrimental effects of load power peaks on $F C$ components. And contrary to most topologies of standard hybridization, it also prevents the $F C$ from high current ripples generated by power electronic converters, as far as current harmonics are mainly supplied by the device with the lowest impedance, meaning the $S C$. The removal of the storage device converter allows a reduction in weight and volume, with a higher reliability (no risk of failure due to the converter, including control). At last, previous theoretical and experimental investigations led with a single $P E M F C$, either short-circuited or hybridized by discharged $S C$, showed that the current cell could be regulated to a level corresponding to the maximal faradaic current allowed by the flow of fed hydrogen [25]. In other words, the cell was observed to act as a perfect current source, controlled by the hydrogen flow rate after Faraday's law. Moreover, this unusual $F C$ operation, which implies a $F C$ voltage far below the threshold recommended by the cell manufacturer, was shown to not affect the aging of the fuel cell, compared with usual operating conditions [26]. As an interesting result, it can be stated that direct hybridization of a single $F C$ with $S C$ does not require any precharge device.

In the present investigation, direct hybridization of fuel cells and supercapacitors is considered for higher durability of the fuel cell itself. For this purpose, a $100 \mathrm{~cm}^{2} P E M$ single cell has been directly hybridized to a stack of three paralleled $3000 \mathrm{~F}$ supercapacitors as shown schematically in Figure 1. The obtained system has been operated in the European harmonized Fuel Cell Dynamic Load Cycle (FC-DLC) [27]. In such cycles, each being 20 min long, the current density is varied according a defined time profile in the range $0-1 \mathrm{~A} \mathrm{~cm}^{-2}$. The flow of reacting gases is to vary accordingly to maintain fixed stoichiometry factors of hydrogen and air oxygen during the cycle, except at very low current density: to avoid possible starvation of the cell caused by insufficient accuracy of the gas flow meters and their slow dynamics, minimum hydrogen and air flow rates are supplied, even at nil or very low current density. For operation in this cyclic mode, in which the gases are fed depending on the current produced by the fuel cell - and not by the (FC-SC) combination (see Figure 1), the presence of the $S C$ can be a potential solution to improve the efficiency in hydrogen use. Besides of efficiency, due to the exponential-like time profiles of the voltages after a sudden change in the system (overall) current, less significant aging in long-term cycling application can be also expected. For this purpose, long-term operations (over $1300 \mathrm{~h} F C-D L C$ ) of hybridized and non-hybridized cells under similar conditions have been compared in terms of both hydrogen consumption and fuel cell (MEA) aging. Fuel cell aging evaluation has been made by means of electrochemical methods, i.e. voltage vs current curves, electrochemical impedance spectroscopy and determination of electrochemical active area and fuel crossover.

In the first part, experimental setup and protocol: materials were described in terms of operating conditions, cycling operation, electrochemical characterization tests. Then, the experimental results associated with comparative the long-term cycling were presented, in particular $F C$ voltage evolution in cycling operation, and electrochemical characterization results: polarization curves, hydrogen crossover, electrochemical active surface area, and various resistance contributions obtained by means of electrochemical impedance spectroscopy (EIS). Finally, hydrogen consumption was determined and discussed in both cases, to evaluate how direct hybridization can contribute to fuel saving.

\section{Experimental Section}

\subsection{Materials and Operating Conditions}

The $100 \mathrm{~cm}^{2}$ single fuel cell (UbzM, Ulm, Germany) consisted in a seven-layer $M E A$ (Paxitech, Echirolles, France) composed of a Nafion ${ }^{\circledR} 21250 \mu \mathrm{m}$ thick membrane, Pt/C electrodes with a $0.4 \mathrm{mg} \mathrm{cm}^{-2}$ and $0.2 \mathrm{mg} \mathrm{cm}^{-2} \mathrm{catalyst}$ loading at the cathode and at the anode respectively, and of $285 \mu \mathrm{m}$ thick GDLs (Freudenberg) including a macroporous carbon fiber paper and a carbon black microporous layer. 
The cell temperature was maintained at $328 \mathrm{~K}$. Humidified air (at $55 \% R H$ ) and dry hydrogen at ambient pressure were supplied to the cathode and anode sides with stoichiometric coefficients of 2.5 and 1.2 respectively for air and hydrogen. Once mounted in the fuel cell, the fresh $M E A$ was preconditioned at $1 \mathrm{~A} \mathrm{~cm}^{-2}$ for $24 \mathrm{~h}$. A first evaluation of the cell was carried out following the protocol detailed in $\$ 2.3$ to characterize the fuel cell in terms of membrane resistance, catalyst activity and fuel crossover at initial state.

In the hybridized mode, a stack of three $3000 \mathrm{~F}$ supercapacitors in parallel (SAFT, Bordeaux, France) was connected to the cell. Two voltage probes have been installed in the circuit for monitoring of voltages $U_{S C}$ and $U_{F C}$ : the presence of wires and connectors is the source of ohmic drops, which explains that the two voltages can differ by up to $300 \mathrm{mV}$ at high current density. One external probe was also installed for monitoring of the fuel cell current $I_{F C}$. The supercapacitor current was simply deduced from the measured load and cell currents. In the presence of the supercapacitors, the gaseous streams were supplied to the $F C$ with the above stoichiometric coefficients $\left(\lambda_{H 2}=1.2\right.$ and $\left.\lambda_{\text {air }}=2.5\right)$, on the basis of the current delivered by the fuel cell, $I_{F C}$ (Figure 1).

\subsection{Cycling Operation}

The bench test was fully controlled by software Controldesk ${ }^{\circledR}$ coupled to a dSPACE ${ }^{\circledR}$ card. By means of the control software, the total current $I_{\text {cycle }}$ was imposed to the 132 A Kikusui active load together with the gas flow rates directly calculated from the cell current, regardless of the hybridization mode (with or without $S C$ ). However, for reasons given above, minimum air and hydrogen flowrates corresponding to $0.2 \mathrm{~A} \mathrm{~cm}^{-2}$ at the fixed $\lambda$ coefficients, were fed to the cell for current density levels inferior to this value. Moreover, without hybridization, because of the time constant of the flow meters, the flow rate set points were changed $5 \mathrm{~s}$ before a positive current step to avoid any starvation risk of the fuel cell during the flow meter transients.

Without hybridization, the cell current and the cycle current are identical (Figure 2). The current and voltage values of both the fuel cell and the supercapacitor (if any) together with the gas flow rates, were recorded every $0.1 \mathrm{~s}$ during the 20 min cycle and the data were saved before starting the following cycle. Figure 2 gives an example of voltage and current variation in one $F C$ - $D L C$ cycle without supercapacitors.

Several long term runs with cyclic operations have been conducted. Each of them consisted in successive series of approx. 300 cycles, i.e. $100 \mathrm{~h}$ or so: after each series, the state of health of the fuel cell has been evaluated by electrochemical characterization procedure (see \$2.3). Whatever the hybridization mode studied in the run, the first $100 \mathrm{~h}$ series after maturation has been conducted with the fuel cell alone: after the second characterization of the cell, the procedure could indicate whether the $M E A$ was running as expected, i.e. following time variations of the voltage and electrochemical features comparable to those in the reference state i.e. without $S C$. When the comparison of the first $100 \mathrm{~h}$ was positive, the run could be continued with or without hybridization, through successive $100 \mathrm{~h}$ cycling periods and characterization stages. The runs shown here were carried out for more than $1300 \mathrm{~h}$ cycling operation.

\subsection{Electrochemical Characterization of the Fuel Cell}

The electrochemical characteristics of the cell were evaluated without supercapacitors in all cases: the characterization stage has been conducted with an Autolab potentiostat coupled with the 132 A Kikusui active load for the polarization curve and electrochemical impedance spectroscopy $(E I S)$, and with a 20 A Autolab Booster for determination of electrochemical active surface area $(E C S A)$ and fuel crossover.

The polarization curve was recorded between 0.1 and $1.2 \mathrm{~A} \mathrm{~cm}^{-2}$, the current was fixed at a given current density $(c d)$ and the voltage was monitored for 10 minutes, allowing to attain the steady state. EIS spectra were then recorded at this $c d$ with an amplitude equal to $10 \%$ of the selected level. The frequency was varied from $10 \mathrm{kHz}$ to $0.1 \mathrm{~Hz}$ with 10 points per decade. EIS measurements were carried out in the range 0.1 to $1 \mathrm{~A} \mathrm{~cm}^{-2}$. An equivalent electric circuit, presented in [28], allowed the ohmic resistance together with the charge transfer and the diffusion resistances to be estimated by fitting of the spectra. Each electrode was represented by a constant phase element in parallel to a charge transfer resistance. At the cathode, a Warburg impedance was also included to express occurrence of diffusion control in oxygen reduction, as shown in Figure 2a. At the anode, the charge transfer resistance was fixed at $10 \%$ of that of the cathode since the anode contribution was so low it could not be precisely distinguished on the Nyquist plot. Figure $2 \mathrm{~b}$ shows on an example the good agreement between experimental and fitted data, in particular with the accurate prediction of the two loops for charge and mass transfer phenomena which validates the model employed. The anode loop could not be distinguished from the far larger cathodic contribution.

For the electrochemical active surface area $(E C S A)$ of the catalyst layer and the fuel crossover through the membrane, fully humidified nitrogen and hydrogen were supplied to the cathode and the anode respectively at $300 \mathrm{STP} \mathrm{mL} \mathrm{min}^{-1}$. ECSA at the cathode was estimated by cyclic voltammetry between 0.05 and $0.6 \mathrm{~V}$ at $30 \mathrm{mV} \mathrm{s}^{-}$ 1 as explained in [29]. Fuel crossover was evaluated by linear sweep voltammetry between 0.05 and $0.6 \mathrm{~V}$ at $2 \mathrm{mV} \mathrm{s}^{-1}$ [30].

\section{Results}




\subsection{Voltage-Current Curves in Cycling Operation}

Variations of the voltage of the cell and of the supercapacitors in cycling operation in hybridized mode or not are presented in this sub-section, and the significance of the two current contributions in the cycle current is examined. The curves discussed in the sub-section have been obtained for time below 200 hours, for which degradation of the fuel cell components was expected to be little significant.

\subsubsection{Non-Hybridized Mode}

As shown in Figure 3, the cycle current is perfectly equal to that delivered by the fuel cell: the expectable result confirms the validity of the current probe calibration. Moreover, the voltage response is nearly instantaneous at low $c d$, but a voltage transient can be observed for current density larger than $0.3 \mathrm{~A} \mathrm{~cm}^{-2}$. In particular, for significant positive steps, as in the two last positive steps of the cycle (Figure 3), the voltage cannot reach a steady level at the end of the $42 \mathrm{~s}$ long current plateau. This is likely due to transient in hydration of the membrane and the catalyst layers, together with gradually more troublesome evacuation of water in the cell at these high $c d$ levels.

\subsubsection{Hybridized Mode}

In Figure 4, the sum of $I_{F C}$ and $I_{S C}$ corresponds perfectly to the controlled current, $I_{c y c l e}$, confirming the correct calibration of the current probes. The role of the $S C s$ appears to smoothen the contribution of the fuel cell in generation of the power: for low $c d$ values, i.e. below $0.3 \mathrm{~A} \mathrm{~cm}^{-2}$, the fuel cell current is larger in the presence of the SCs than those in the conventional mode, and allows charge of the supercapacitors (with a negative current in these periods). In particular, for periods at zero cycle current, because of its contribution in charging the $S C$, the fuel cell has a voltage at least $100 \mathrm{mV}$ lower than the usual $O C V$, which is to limit the degradation of the fuel cell components. For larger current density, mainly in the third phase of the cycle, the SCs act as generator in conjunction with the fuel cell, whose specific current is somewhat lower. As a consequence, the cell voltage in high power production is higher than without hybridization. The smoothened current response of the fuel cell logically results in smoothened variations of its potential during the cycle.

Besides, as expressed in the previous section, the voltage difference in the cell and the supercapacitors is caused by the ohmic drop in the connecting wires.

\subsection{Fuel Cell Aging in Hybridized and Non-Hybridized Modes}

\subsubsection{Voltage Evolution in Cycling Operation}

It appears from Figure 5 that the fuel cell voltage was decreased by the long term run, in both hybridization modes. This phenomenon is more visible for $c d$ larger than $0.5 \mathrm{~A} \mathrm{~cm}^{-2}$, with cell voltage reduction in the order of $150 \mathrm{mV}$. As shown by Figure 6, for the fuel cell alone, a sudden decrease of the cell voltage upon the current step was observed, but with a negative overshot. As a matter of fact, after a few seconds the voltage increases again to attain a steady level. After $100 \mathrm{~h}$ cycling, the overshot defined as the difference between the voltage minimum and the steady state level is low, at $16 \mathrm{mV}$. In contrast, at the end of aging run $(1350 \mathrm{~h})$, the overshot attains $94 \mathrm{mV}$ and steady behavior is attained after a longer transient period. With the presence of supercapacitors, the above overshot is not more visible and the voltage response continuously decreases during the period at $0.583 \mathrm{~A} \mathrm{~cm}^{-2}$ : the transient phase exceeds the approx. $57 \mathrm{~s}$ long period at $0.583 \mathrm{~A} \mathrm{~cm}^{-2}$. Moreover, upon aging, the cell response in potential becomes some larger, as indicated in Figure 5 by the still decreasing profile of the cell voltage.

For each cycle, maximum and minimum voltages $U_{\max }$ and $U_{\min }$ respectively, have been extracted from the recorded data. The average voltage, $U_{\text {mean }}$, has been calculated by averaging the fuel cell voltage over the studied cycle (Figure 7).

As shown in Figure $7 \mathrm{a}$, the average voltage $U_{\text {mean }}$ in the two runs were very close to each other, at $0.74 \mathrm{~V}$ after $100 \mathrm{~h}$ and $0.66 \mathrm{~V}$ at the end of the run. However, it can be noticed that in each $100 \mathrm{~h}$ long periods between characterizations, the cell voltage decay was more pronounced with hybridization than without. This sharp cell improvement after characterization often observed [31,32] is partly due to voltammetric investigations, in particular to the low voltage periods in which slight oxidised Pt clusters can be fully reduced to metal Pt: with hybridization, the voltage jump was larger than in conventional mode. Nevertheless, after the first $100 \mathrm{~h}$ cycling, the decay rate calculated from $\mathrm{t}=100 \mathrm{~h}$ to $1350 \mathrm{~h}$ was little affected by hybridization mode, being at $44 \mu \mathrm{V} \mathrm{h}^{-1}$ with supercapacitors and $46 \mu \mathrm{V} \mathrm{h}^{-1}$ in non-hybridized mode.

The maximum voltage $U_{\max }$ (Figure $7 \mathrm{~b}$ ) with hybridization is more than $100 \mathrm{mV}$ lower than in conventional mode as expressed above, starting at 0.82 and $0.98 \mathrm{~V}$ respectively. Without hybridization $U_{\max }$ corresponds to $O C V$; but with supercapacitors the cell produces continuously current to charge the $S C s$ and/or to supply the load. Along the aging run, the two maximum voltages decreased with an average rate at $25 \mu \mathrm{V} \mathrm{h}^{-1}$ up to $\mathrm{t}=1200 \mathrm{~h}$; in the last 150 hours of the run, the decay was much more pronounced in non-hybridized mode than with the presence of supercapacitors, at $185 \mu \mathrm{V} \mathrm{h}^{-1}$ and $46 \mu \mathrm{V} \mathrm{h}^{-1}$ respectively. This fact can appear in consistence with the larger increase in fuel crossover observed with the fuel cell alone, as presented later. 
The minimum voltage of the cell, $U_{\min }$, (Figure $7 \mathrm{c}$ ) usually corresponds to the cycle period at $1 \mathrm{~A} \mathrm{~cm} \mathrm{~cm}^{-2} \mathrm{delivered}$ to the load. $U_{\min }$ is visibly lower in non-hybridized mode $(0.40 \mathrm{~V})$ than with supercapacitors at $0.50 \mathrm{~V}$ after $100 \mathrm{~h}$. As expressed above, this is also a consequence of the smoothening action of the supercapacitors which actually act as generators for high $c d$ demand. This explains the difference in $U_{\min }$ values. This minimum was in all cases subject to significant decay within the continuous $100 \mathrm{~h}$ cycling periods and to appreciable increase by the characterization, presumably for the above reasons. Within the $100-1200 \mathrm{~h}$ period, the average $U_{\min }$ decay was little affected by the hybridization state, at approx. $100 \mu \mathrm{V} \mathrm{h}^{-1}$ in conventional mode, and $92 \mu \mathrm{Vh}^{-1}$ with supercapacitors. In the last phase of the runs, the decay was more pronounced, in particular without supercapacitors.

In spite of the differences in the average, maximum and minimum voltages, the impact of hybridization on the tolerance to aging does not appear clearly from this investigation, except in the final phase of the aging runs, for which the voltage decay is more pronounced without supercapacitors than in hybridized state.

\subsubsection{Fuel Cell Aging Characterization}

\section{Polarization curves}

Figure 8 shows the polarization curves obtained after 100 and $1350 \mathrm{~h}$ cycling, depending on the hybridization mode. In both modes, aging induced by $F C$-DLC cycling results in decreased cell voltage, the decrease appearing as more important as the cycle current density is larger; this would indicate that aging has a larger impact on mass transfer rates than on charge transfer kinetics. At $1 \mathrm{~A} \mathrm{~cm}^{-2}$, the voltage reduction in the $100-1350 \mathrm{~h}$ period attained comparable values with and without hybridization, at 190 and $210 \mathrm{mV}$ respectively. For larger current density, the role of hybridization appears more significant, with corresponding voltage difference at 230 and $410 \mathrm{mV}$ respectively at $1.1 \mathrm{~A} \mathrm{~m}^{-2}$ (Figure 8 ); the non-hybridized cell could not deliver a stable voltage at $1.2 \mathrm{~A} \mathrm{~cm}^{-2}$ after $1350 \mathrm{~h}$. Although to a moderate extent, the presence of supercapacitors hinders the effects of the aging at high current density, in a way that it seems to protect the mass transfer performance of the cell.

\section{Hydrogen crossover and Electroactive catalyst surface area}

Figure 9a shows the time variation of the membrane permeability to hydrogen (fuel crossover) expressed in the form of the current density for oxidation of the permeation flux in the two hybridizations states. In both cases, the fuel crossover is close to $0.8 \mathrm{~mA} \mathrm{~cm}^{-2}$, in consistence with the usual values for 1 mil thick Nafion membranes, near $1 \mathrm{~mA} \mathrm{~cm}^{-2}$ [33]. The fuel crossover varies very little, in comparable manner in the two runs of interest until $1100 \mathrm{~h}$. Then, a sudden increase in the last period of the run occurs, in particular without hybridization, expressing the formation of a defect in the membrane. With hybridization, the crossover attains $6.3 \mathrm{~mA} \mathrm{~cm}^{-2}$ at the end of the run whereas it could not be measured with accuracy without hybridization because of the strongly inclined profile of the $L S V$ and $C V$ curves: this continuously increasing current with the potential expressed the existence of a finite short circuit resistance between the anode and cathode compartments [34] (without supercapacitors). The postulated contact between the two chambers was confirmed by the presence of holes observed in the membrane after the run. Long-term $F C$ - $D L C$ cycling likely generated mechanical fatigue of the ionomer resulting in local perforation, which can explain the strong increase in the crossover to abnormal values. The visible decrease in the $O C V$ observed in Figure $7 \mathrm{~b}$ is likely related to the above sharp increase after $1200 \mathrm{~h}$ (Figure 10), in agreement with the literature [35].

Variations of the electrochemical active surface (ECSA) in the two runs are given in Figure 9b. The initial values of ECSA differed by approx. $15 \%$ from each other: therefore, it has been preferred to compare their variations with reference to the initial values. As a matter of fact, the cathodes in the two MEA's exhibited very comparable, regular variations, with a decay rate at approx. $6 \% \mathrm{~h}^{-1}$ : hybridization actually does not affect significantly the catalyst aging upon cycling.

\section{Electrochemical impedance spectroscopy}

Although EIS has been conducted at each characterization step at 0.1 and between 0.2 and $1 \mathrm{~A} \mathrm{~cm}^{-2}$ every $0.2 \mathrm{~A} \mathrm{~cm}$ ${ }^{2}$, presentation of the results obtained has been limited to two current densities: $0.2 \mathrm{~A} \mathrm{~cm}^{-2}$, more relevant to chargetransfer controlled operation, and $0.8 \mathrm{~A} \mathrm{~cm}^{-2}$ for which mass transfer limitation can be more visible. Time variations in the impedance spectra is exemplified for the case of $0.8 \mathrm{~A} \mathrm{~cm}^{-2}$ in Figure 11, with in particular very little change in the ohmic resistance but sustained, significant increase in the overall charge transfer and diffusion resistance, as discussed more in detail below.

Figure 12 compares the time variations of the ohmic resistance and the resistances at the cathode in fuel cells operated in $F C$-DLC operation, with and without hybridization at the two $c d$ levels.

The initial value of the ohmic resistance was not the same in the two $M E A$ 's tested, at 0.14 and $0.18 \Omega \mathrm{cm}^{2}$ (Figure 12a). In both hybridization states, this resistance varied regularly but very little along the cycling run, with a final increase at approx. $10 \%$.

The charge transfer resistances at the cathode $\left(R_{c}\right)$ exhibit regular and comparable enhancement along time for the two MEA's and at the two $c d$ 's: at $0.2 \mathrm{~A} \mathrm{~cm}^{-2}, R c$ was found to be approx. 1.6 times larger than the initial value without or with hybridization, and at $0.8 \mathrm{~A} \mathrm{~cm}^{-2}$, it is close to 3 (Figure 12b). 
As shown in Figure $12 \mathrm{c}$, the diffusion resistance at the cathode $\left(R_{\text {diff, }, c}\right)$ varied along time less at high current density. At $0.2 \mathrm{~A} \mathrm{~cm}^{-2}$, without supercapacitors, the profile is regular and the final value is approx. 2.3 times larger than the initial value. At $0.8 \mathrm{~A} \mathrm{~cm}^{-2}$ in this configuration, the diffusion resistance seems to remain constant. With hybridization, the corresponding factors at final time attained 2.7 and approx. 1.6 respectively. Care has to be taken in this discussion because the charge transfer and the diffusion resistance could not be extracted with accuracy from the overall loop obtained at $0.8 \mathrm{~A} \mathrm{~cm}^{-2}$ - whereas the two contributions can be clearly distinguished at low $c d$ : for the larger $c d, R_{d i f f, c}$ could then be underestimated with a overestimated value for $R_{c}$, or vice versa.

For the above reason, the sum of the two resistances has been plotted (Figure 12d): the four variations with time exhibit comparable profiles, with increase factors ranging from 1.6 to 2 : the upper value corresponds to the cell operated hybridized at high $c d$.

Nevertheless, the aging of the two MEAs as expressed by the various resistance contributions examined, differs only little from each another: EIS did not fully evidence that hybridization with large supercapacitors could greatly reduce the significance of aging upon $F C$ - $D L C$ cycling.

\subsection{Hybridization for an Improved Energy Management}

From the set of recorded data, the gas consumptions could be calculated by numerical integration over time. The results for hydrogen are given in Figure 13. It can be first observed that the gas consumption did not vary significantly along the cycling runs, as expected. Besides, when the cell is operated alone, taking into account the stoichiometric factor, the average flow rate of fed hydrogen is $0.297 \mathrm{NL} \mathrm{min}^{-1}$, corresponding to $5.94 \mathrm{NL} \mathrm{cycle}^{-1}$. The minimum hydrogen consumption associated with the considered $F C$-DLC being $3.86 \mathrm{NL}^{-1}$ cycle $^{-1}$ (calculated with a unity $\mathrm{H}_{2}$ stoichiometric factor and Faraday's law, with no minimum flow rate, and with no flow rate anticipation before positive current slopes), the hydrogen overconsumption is then $2.08 \mathrm{NL}_{\text {cycle }}^{-1}$ when the cell is operated alone. is operated alone. Using Faraday's law and integrating the data recorded within one cycle, it can be shown that the overconsumption is due:

(i) by $37 \%$ to the $\mathrm{H}_{2}$ stoichiometric factor $(1.2$, instead of 1$)$,

(ii) by $52 \%$ to the minimum $\mathrm{H}_{2}$ flow rate (corresponding here to $0.2 \mathrm{~A} \mathrm{~cm}^{-2}$ ),

(iii) by $11 \%$ to the $\mathrm{H}_{2}$ flow rate anticipation before positive current slopes ( $5 \mathrm{~s}$ anticipation).

In the presence of the three SCs in parallel, and controlling the gas flow rates on the basis of the current supplied by the fuel cell, the average hydrogen flow rate is only at $0.250 \mathrm{NL} \mathrm{min}^{-1}$, i.e. $5.00 \mathrm{NL} \mathrm{cycle}^{-1}$ (Figure 13), corresponding to a $16 \%$ reduction in gas consumption, and to a $45 \%$ reduction in gas waste. The above reductions result from two main factors: first, as expressed above in the non-hybridized mode, the flow rate set points were changed a few seconds before each positive current step, whereas the presence of supercapacitors allowed this safety procedure to be avoided. The second reason is related to the minimum gas flow rates equivalent to $0.2 \mathrm{~A} \mathrm{~cm}^{-}$ 2 as follows: without hybridization, for current density $i_{F C}$ below $0.2 \mathrm{~A} \mathrm{~cm}^{-2}$, the hydrogen flux corresponding to the difference $\left(0.2-i_{F C}\right)$ is lost. In contrast, with supercapacitors in periods with a low current density $i_{c y c l e}$ in the system, the fuel cell operates at a current density larger than $i_{\text {cycle, }}$, corresponding to the transient charge of the supercapacitors: then the wasted hydrogen flux proportional to $\left(0.2-i_{F C}\right)$ is lower than that without supercapacitors. For the sake of easier understanding, the two phenomena are illustrated for the two hybridization modes in Figure 14 on the basis of recorded data: the amounts of lost hydrogen are proportional to the dashed areas in the figure, with a visibly lower significance with the supercapacitors. As a result, the $\mathrm{H}_{2}$ over-consumption due to the minimum $\mathrm{H}_{2}$ flow rate is $0.37 \mathrm{NL}_{\text {cycle }}{ }^{-1}$, whereas it represents $1.08 \mathrm{NL}_{\text {cycle }}{ }^{-1}$, without hybridization.

\section{Conclusion}

After $1350 \mathrm{~h}$, the comparison of the two set-ups (hybridized and non-hybridized modes) did not show significant differences. The electrical performance, the resistances evolution and the ECSA values were very close. Only $\mathrm{H}_{2}$ crossover seems to be reduced in hybridized mode. If these first tests did not highlight higher $F C$ durability when hybridized, they emphasized that direct hybridization of $F C$ to $S C$ was technically sustainable and that they did not damage prematurely the $F C$. Further tests will consist in optimize the set-up to emphasize the beneficial impact of the direct hybridization on the $F C$ aging. A positive result of this present investigation relied on a $16 \%$ decrease of hydrogen consumption in the hybridized mode compared to the $F C$ alone. With hybridization, because of the dampening action of the $S C$, the minimum gas flow rate might be largely reduced, so could the stoichiometric factor of hydrogen, for the sake of still reduced $\mathrm{H}_{2}$ consumption.

\section{Acknowledgements}

This work was supported partly by the French PIA project «Lorraine Université d'Excellence», reference ANR15-IDEX-04-LUE for the PhD grant allocated to D. Arora. 


\section{References}

[1] H.-C.B. Jensen, E. Schaltz, P.S. Koustrup, S.J. Andreasen, K.S. Knudsen, IEEE Trans. Veh. Technol. 2013, 62, 50 .

[2] L. Schindele, M. Braun, H. Spath, The influence of power electronic dynamics on PEM fuel cell-system, EPE 2005, Dresden, September, 2005, pp. 1-9.

[3] P. Thounthong, P. Sethakul, Analysis of a fuel starvation phenomenon of a PEM fuel cell, IEEE-PPC 2007, Nagoya, April, 2007, pp. 731 .

[4] A. Taniguchi, T. Akita, K. Yasuda, Y. Miyazaki, J. Power Sources 2004, 130, 42.

[5] B. Wahdame, L. Girardot, D. Hissel, F. Harel, X. François, D. Candusso, M.-C. Péra, L. Dumercy, Impact of power converter current ripple on the durability of a fuel cell stack, IEEE-ISIE 2008, Cambridge, June-July, 2008, pp. 1495.

[6] M.A. Al-Saffar, E.H. Ismail, Renew. Energ. 2015, 82, 35.

[7] M. Gerard, J.-P. Poirot-Crouzevier, D. Hissel, M.-C. Péra, ASME J. Fuel Cell Sci. Technol. 2011, 8, 021004$1 / 5$.

[8] B.P. Ladewig, F. Lapicque, Fuel Cells 2009, 9, 157.

[9] G. Fontes, C. Turpin, S. Astier, T. Meynard, IEEE Trans. Power Electron. 2007, 22, 670.

[10] D. Guilbert, A. Gaillard, A. Mohammadi, A. N'Diaye, A. Djerdir, Int. J. Hydrogen. Energy 2015, 40, 519.

[11] L.P. Jarvis, T.B. Atwater, P.J. Cygan, J. Power Sources 1999, 79, 60.

[12] T.B. Atwater, P.J. Cygan, F.C. Leung, J. Power Sources 2000, 91, 27.

[13] J.S. Martinez, D. Hissel, M.C. Péra, M. Amiet, IEEE Trans. Veh. Technol. 2011, 60, 4139.

[14] J. Bernard, S. Delprat, F.N. Büchi, T.M. Guerra, IEEE Trans. Veh. Technol. 2009, 58, 3168.

[15] I. Lachhab, L. Krichen, Int. J. Hydrogen Energy 2014, 39, 571.

[16] H. Aouzellag, K. Ghedamsi, D. Aouzellag, Int. J. Hydrogen Energy 2015, 40, 7204.

[17] P. Garcia, J.P. Torreglosa, L.M. Fernandez, F. Jurad, Int. J. Hydrogen Energy 2012, 37, 9368.

[18] Q. Li, W. Chen, Z. Liu, M. Li, L. Ma, J. Power Sources 2015, $279,267$.

[19] A. Nishizawa, J. Kallo, O. Garrot, J. Weiss-Ungethüm, J. Power Sources 2013, 222, 294.

[20] P. Thountong, V. Chunkag, P. Sethakul, S. Sikkabut, S. Pierfederici, B. Davat, J. Power Sources 2001, 196, 313.

[21] Y. Zhan, Y. Guo, J. Zhu, L. Li, Elect. Power and Energy Syst. 2015, 67, 598.

[22] P.B. Jones, J.B. Lakeman, G.O. Mepsted, J.M. Moore, J. Power Sources 1999, 80, 242.

[23] B. Wua, M.A. Parkes, V. Yufit, L. De Benedetti, S. Veismann, C. Wirsching, F. Vesper, R.F. Martinez-Botas, A.J. Marquis, G.J. Offer, N.P. Brandon, Int. J. Hydrogen Energy 2014, 39, 7885.

[24] B. Morin, D. Van Laethem, C. Turpin, O. Rallières, S. Astier, A. Jaafar, O. Verdu, M. Plantevin, V. Chaudron, Fuel Cells 2014, 14, 500.

[25] M. Hinaje, S. Raël, J.-P. Caron, B. Davat, Int. J. Hydrogen Energy 2012, 37, 12481.

[26] C. Bonnet, F. Lapicque, M. Belhadj, K. Gérardin, S. Raël, M. Hinaje, L. Mitchell, V. Goldsmith, S.J. Kmiotek, Fuel Cells 2017, 17, 157.

[27] http://publications.jrc.ec.europa.eu/repository/bitstream/JRC99115/ldna27632enn.pdf, pp.38.

[28] B.T. Huang, Y. Chatillon, C. Bonnet, F. Lapicque, S. Leclerc, M. Hinaje, S. Raël, Fuel Cells 2012, $12,335$.

[29] A. M. Chaparro, A.J. Martin, M.A. Folgado, B. Gallardo, L. Daza, Int. J. Hydrogen. Energy 2009, $34,4838$.

[30] M. Inaba, T. Kinumoto, M. Kiriake, R. Umebayashi, A. Tasaka, Z.Ogumi, Electrochim. Acta 2006, $51,5746$.

[31] S.J.C. Cleghorn, D.K. Mayfield, D.A. Moore, J.C. Moore, G. Rusch, T.W. Sherman, N.T. Sisofo, U. Beuscher, J. Power Sources 2006, 158, 446.

[32] F. Lapicque, C. Bonnet, B.T. Huang, Y. Chatillon, in Advances in Chemical Engineering, Vol. 41 (Ed. K. Sundmacher), Elsevier, Amsterdam, 2012, pp. 265.

[33] C. Francia, V.S. Ijeri, S. Specchia, P. Spinelli, J. Power Sources 2011, 196, 1833.

[34] B.T. Huang, Y. Chatillon, C. Bonnet, F. Lapicque, S. Leclerc, M. Hinaje, S. Raël, Int. J. Hydrogen. Energy 2013, 38, 543.

[35] D. Liu, S. Case, J. Power Sources 2006, 162, 521.

\section{Figure Captions}

Fig. 1 Direct hybridization between the fuel cell $(F C)$ and the supercapacitors $(S C)$.

Fig. 2 a) Equivalent circuit used for EIS fitting. b) Examples of experimental and fitted spectra at $0.2 \mathrm{~A} \mathrm{~cm}^{-2}$ after 100 hours run without $S C$.

Fig. 3 Current delivered by the $100 \mathrm{~cm}^{2}$ fuel cell $\left(I_{F C}\right)$ (in red) and its voltage $\left(V_{F C}\right)$ (in green), together with the cycle current $I_{c y c l e}$ (in yellow) in a $F C$ - $D L C$ cycle without supercapacitors.

Fig. 4 Current delivered by the $100 \mathrm{~cm}^{2}$ fuel cell $\left(I_{F C}\right)$, current passing through the supercapacitor $\left(I_{S C}\right)$, with the cycle current, together with the fuel cell and $S C$ voltages for a $F C$ - $D L C$ cycle with hybridization (at $200 \mathrm{~h}$ ). Fig. 5 Potential response of the fuel cell after $100 \mathrm{~h}$ and $1350 \mathrm{~h}$ cycling operation, with hybridization or not. Fig. 6 Zoomed view of the fuel cell potential response to the current step at $842 \mathrm{~s}$ (from 5 to $58.3 \mathrm{~A}$, i.e. 0.05 to $0.583 \mathrm{~A} \mathrm{~cm}^{-2}$ ), cell after $100 \mathrm{~h}$ and $1350 \mathrm{~h}$ cycling operation, with hybridization or not. 
Fig. 7 a) Fuel cell voltage averaged over one cycle $\left(U_{\text {mean }}\right)$. b) Maximum fuel cell voltage in a cycle $\left(U_{\max }\right)$. c) Minimum fuel cell voltage in a cycle $\left(U_{\min }\right)$.

Fig. 8 Polarization curves after après $100 \mathrm{~h}$ and $1350 \mathrm{~h}$ cyclic operation in the two hybridization modes. Fig. 9 Aging of the cell under $F C$ - $D L C$ cycling depending on the hybridization mode. a) Membrane permeability to hydrogen expressed as a current density. b) Electrochemical active surface (ECSA) of the catalyst.

Fig. 10 Hydrogen crossover and fuel cell $O C V$ over time: simultaneous occurrence of sudden changes.

Fig. 11 Examples of EIS recorded at $0.8 \mathrm{~A} \mathrm{~cm}^{-2}$ during the aging run without $\mathrm{SC}$

Fig. 12 a) Ohmic resistance $\left(R_{o h m}\right)$. b) Charge transfer resistance at the cathode $\left(R_{c}\right)$. c) Diffusion resistance at the cathode $\left(R_{\text {diff,c }}\right)$. d) Polarization resistance defined as $\left(R_{c}+R_{\text {diff,c }}\right)$.

Fig. 13 Average volume flow rate of hydrogen over time depending on the hybridization mode.

Fig. 14 Zoomed view of the cell current $I_{F C}$ during FC-LDC cycle (after 300 hours) depending on the hybridization mode. The current corresponding to the minimum gas flow rate is also shown. The dashed areas are proportional to the amount of hydrogen lost in the operation, regardless of the $5 \mathrm{~s}$ time period between the changes in the flow rate set points and the positive current step. 


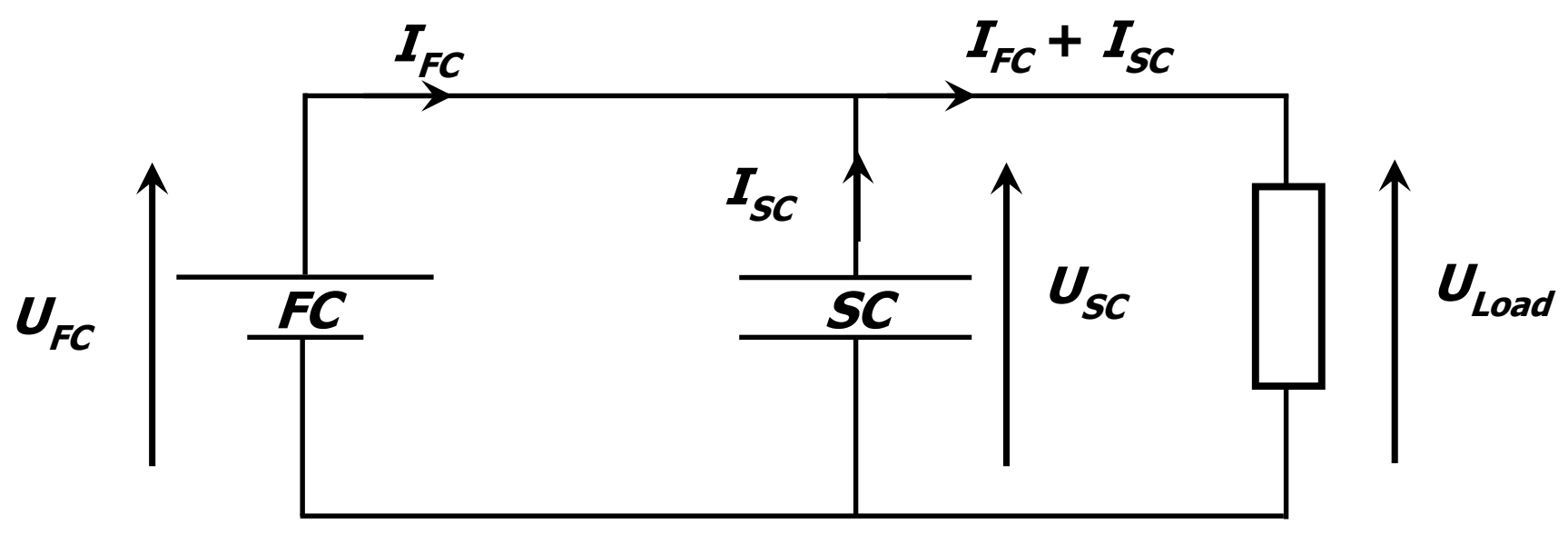

Figure 1: Direct hybridization between the fuel cell and the supercapacitors. 


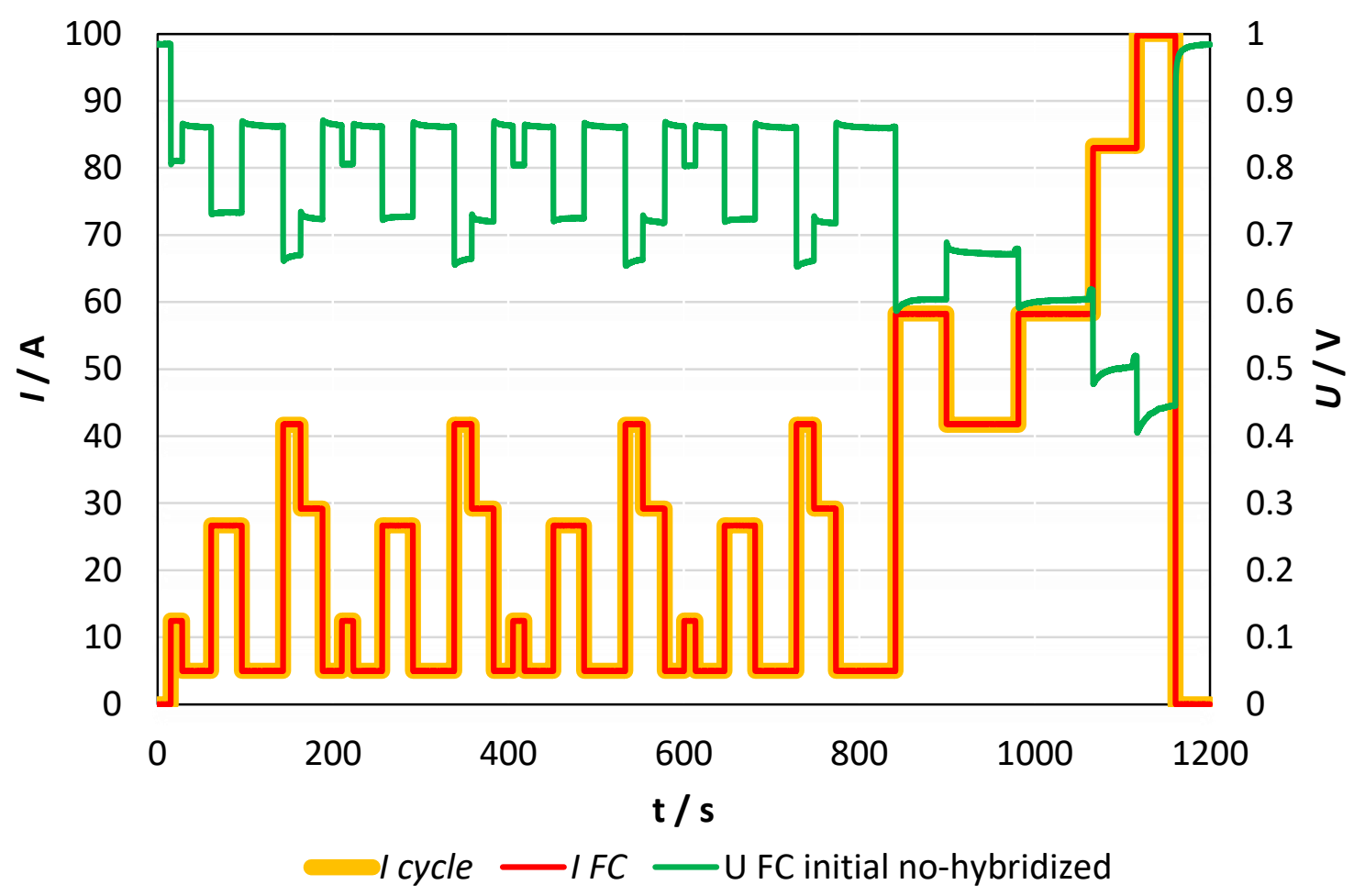

Figure 2: Current delivered by the $100 \mathrm{~cm}^{2}$ cell $\left(\mathrm{I}_{\mathrm{FC}}\right)$ (in red) and its voltage $\left(\mathrm{V}_{\mathrm{FC}}\right)$ (in green), together with the cycle current $\mathrm{I}_{\text {cycle }}$ (in yellow) in a FC-DLC cycle without supercapacitors. 


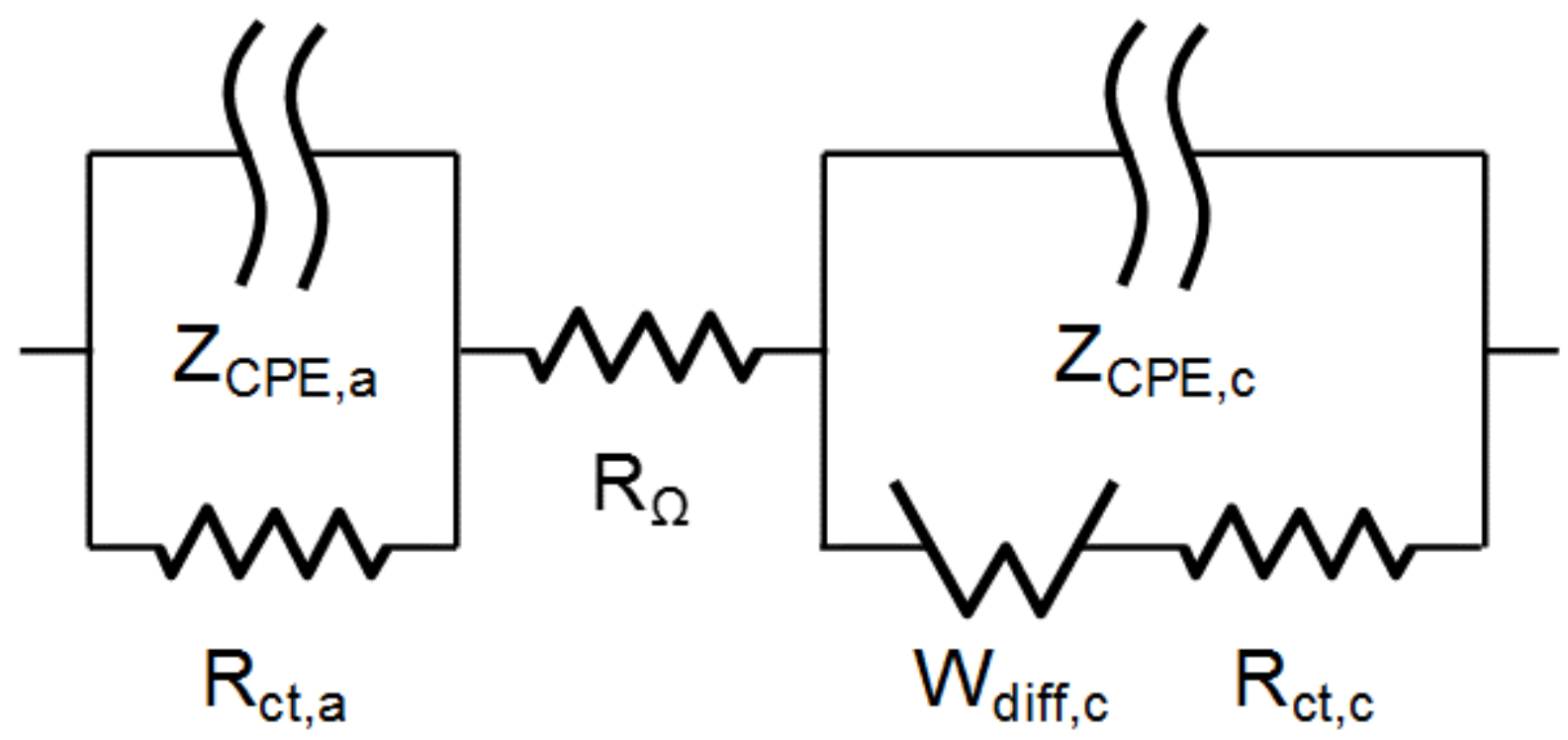

Figure 3 a): Equivalent circuit used for EIS fitting. 


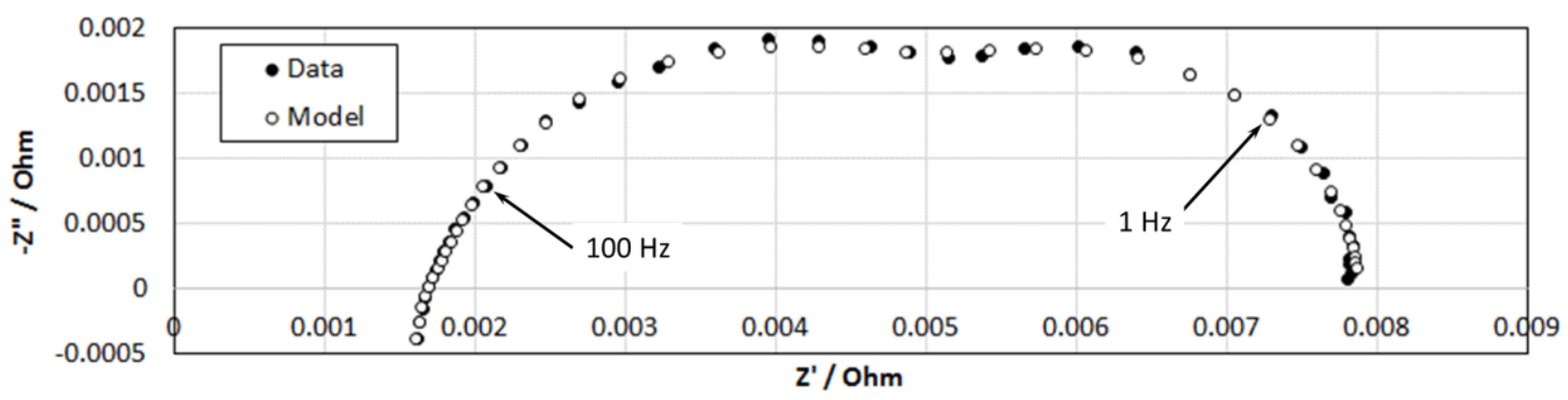

Figure $3 \mathrm{~b}$ ): Examples of experimental and fitted spectra at $0.2 \mathrm{~A} \mathrm{~cm}^{-2}$ after 100 hours run without SC. 


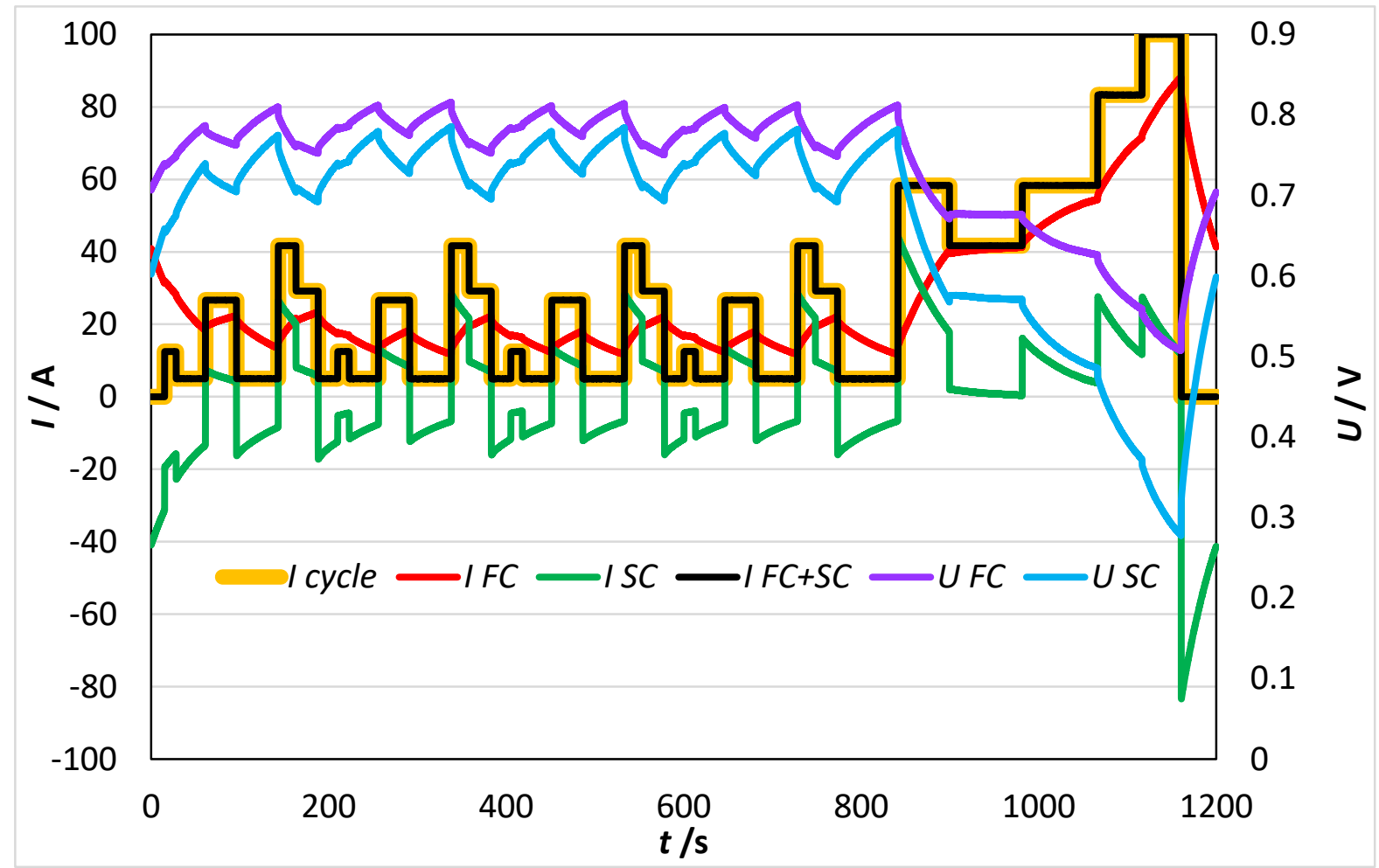

Fig. 4 Current delivered by the $100 \mathrm{~cm}^{2}$ cell $\left(\mathrm{I}_{\mathrm{FC}}\right)$, current passing through the supercapacitor $\left(\mathrm{I}_{\mathrm{SC}}\right)$, with the cycle current, together with the cell and SC voltages for a FC-DLC cycle with hybridization (at $200 \mathrm{~h}$ ). 


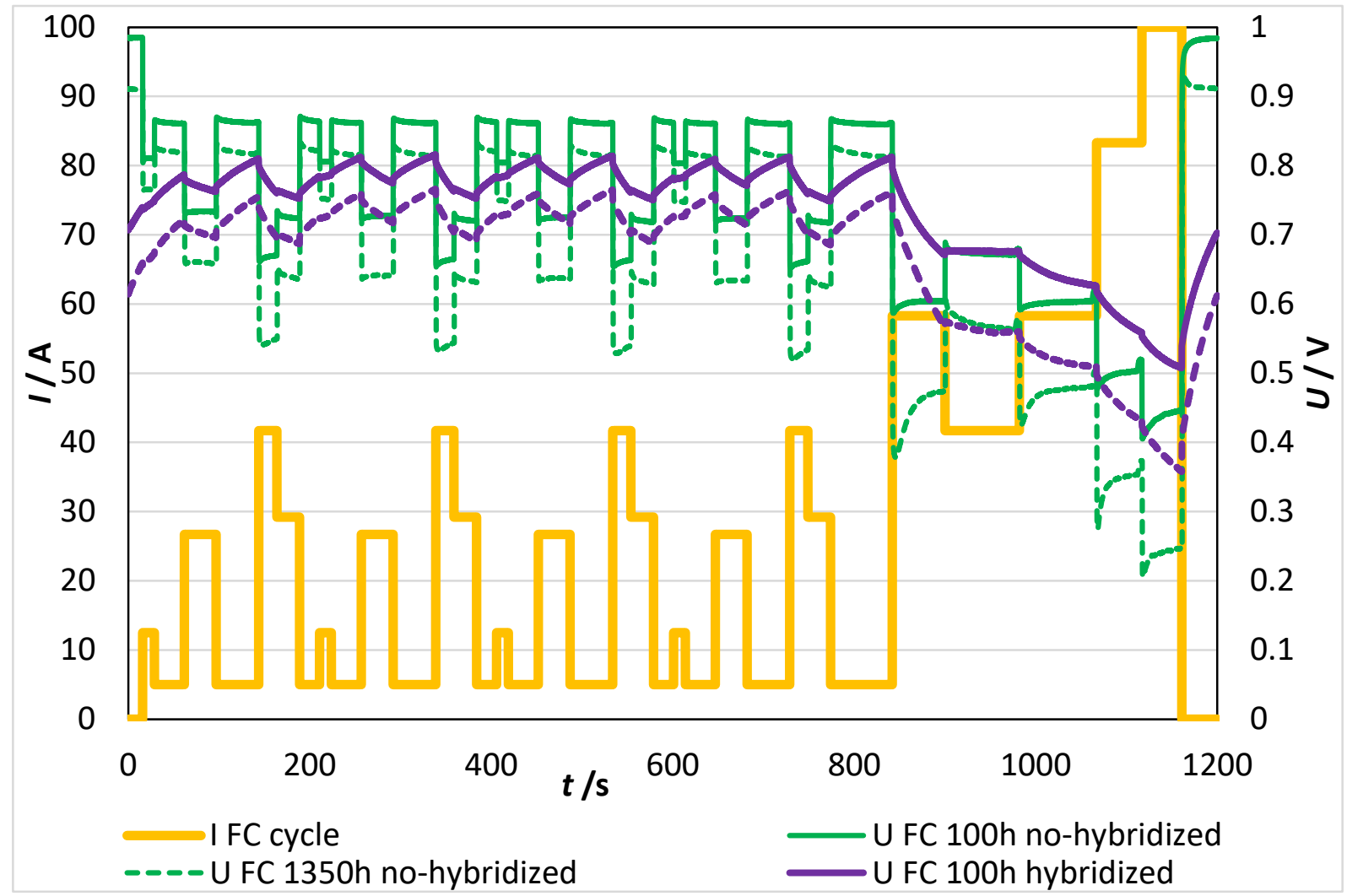

Figure 5: Potential response of the fuel cell after $100 \mathrm{~h}$ and $1350 \mathrm{~h}$ cycling operation, with hybridization or not. 


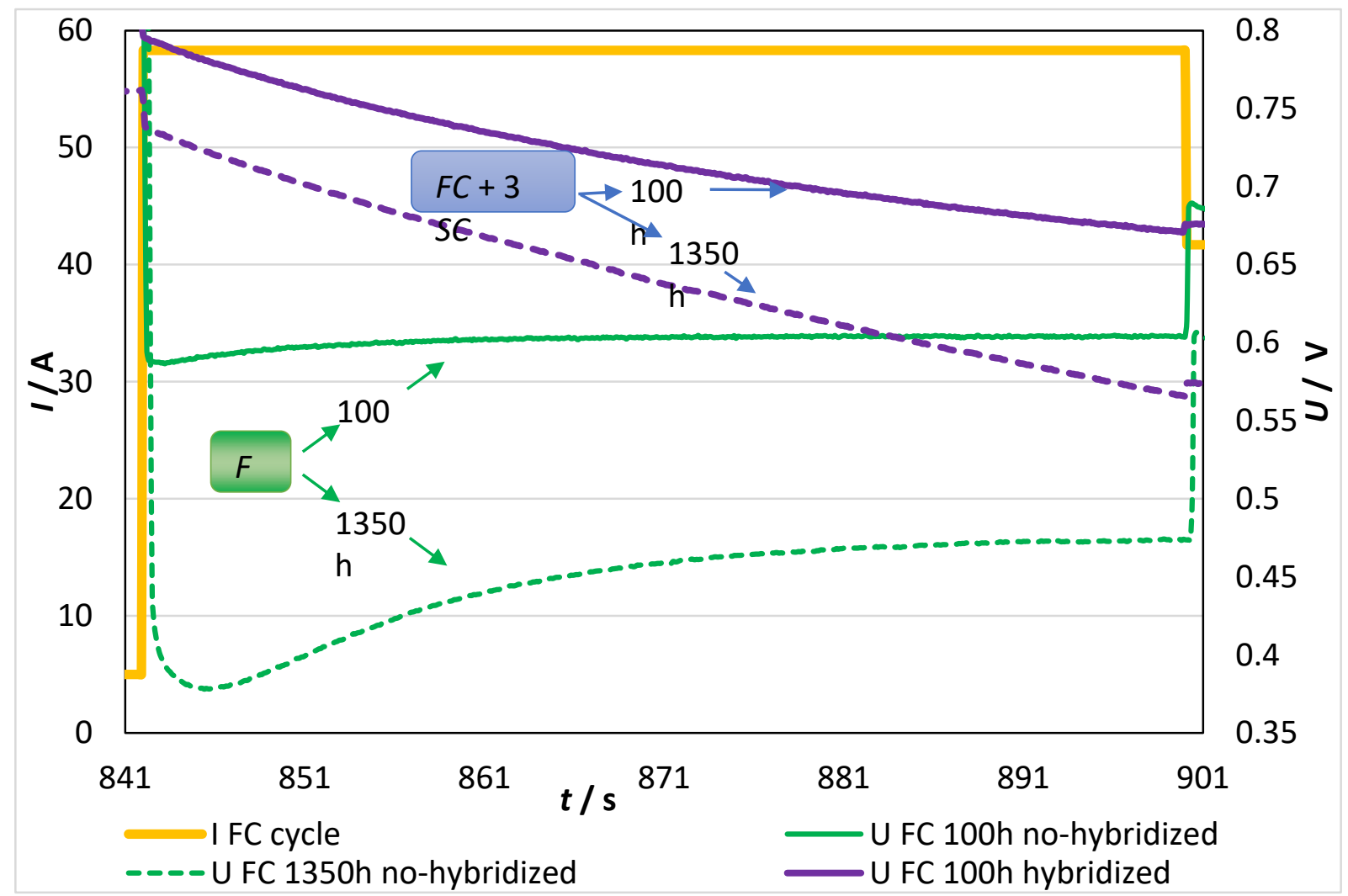

Figure 6: Zoomed view of the cell potential response to the current step at $842 \mathrm{~s}$ (from 5 to $58.3 \mathrm{~A}$, i.e. 0.05 to $0.583 \mathrm{~A} \mathrm{~cm}^{-2}$ ), cell after $100 \mathrm{~h}$ and $1350 \mathrm{~h}$ cycling operation, with hybridization or not. 

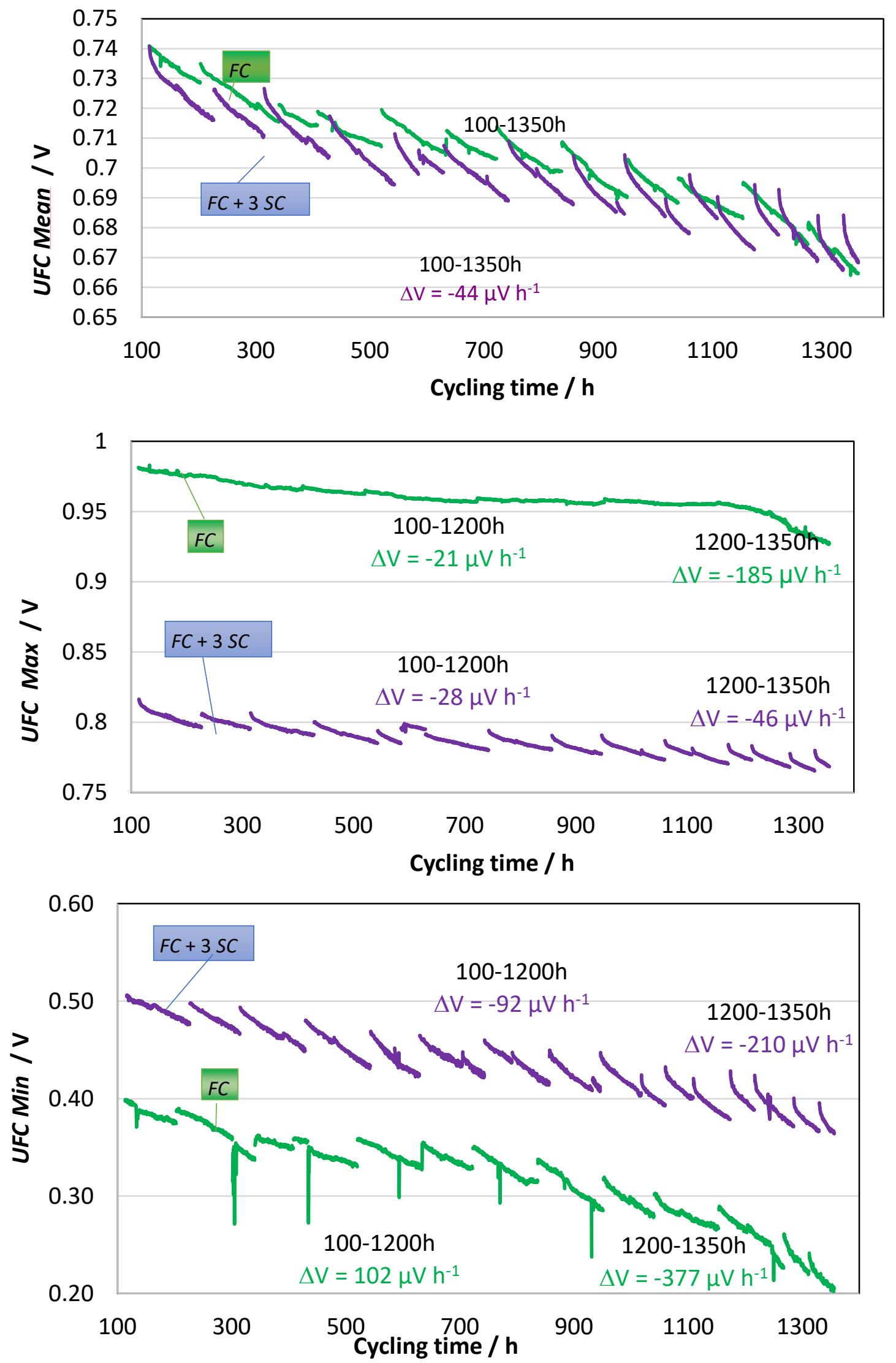

Figure 7a): Cell voltage averaged over one cycle $\left.\left(U_{\text {mean }}\right) . b\right)$ Maximum cell voltage in a cycle $\left(\mathrm{U}_{\max }\right)$. c) Minimum cell voltage in a cycle $\left(\mathrm{U}_{\mathrm{min}}\right)$. 


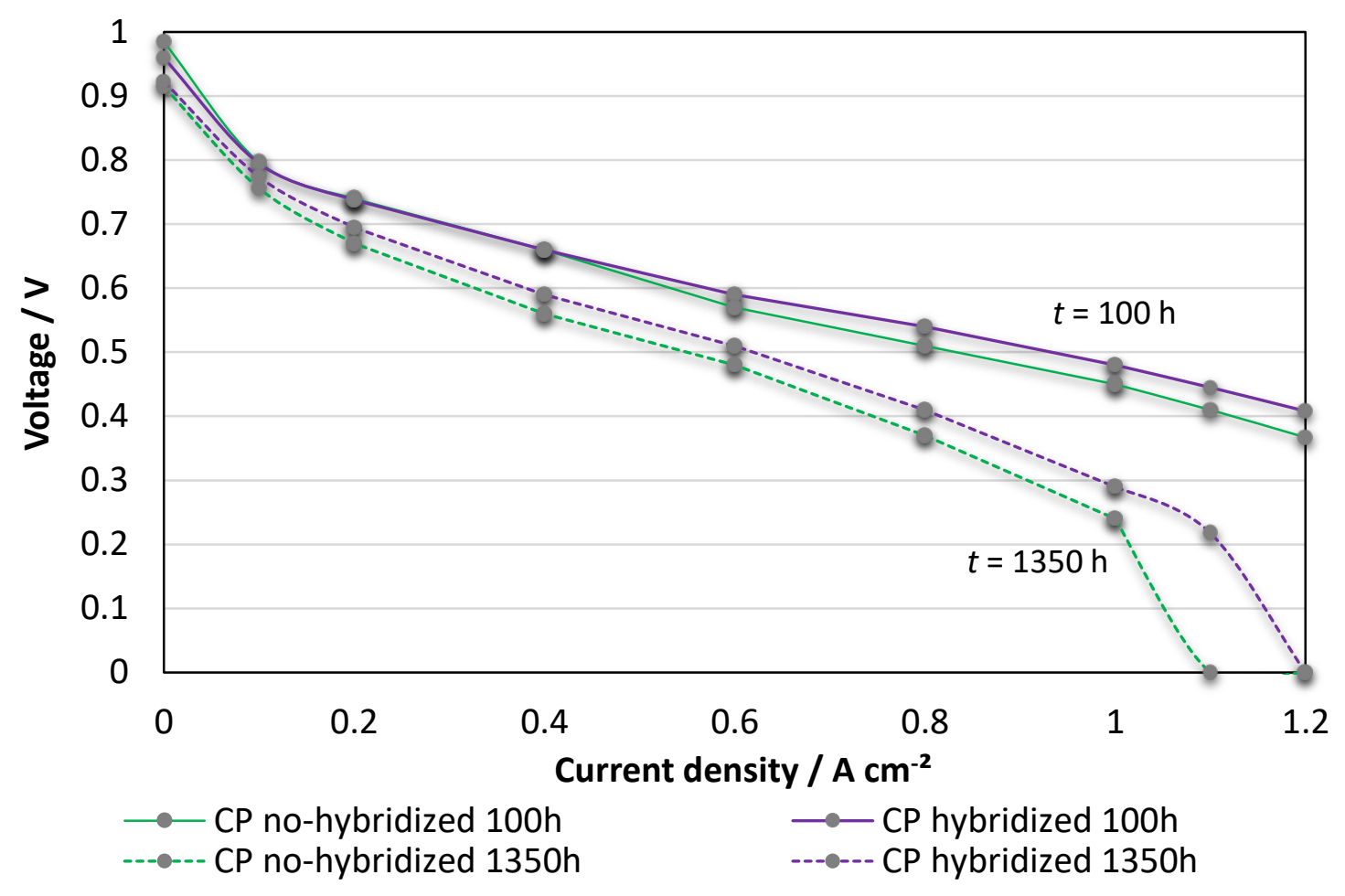

Figure 8: Polarization curves after après $100 \mathrm{~h}$ and $1350 \mathrm{~h}$ cyclic operation in the two hybridization modes. 

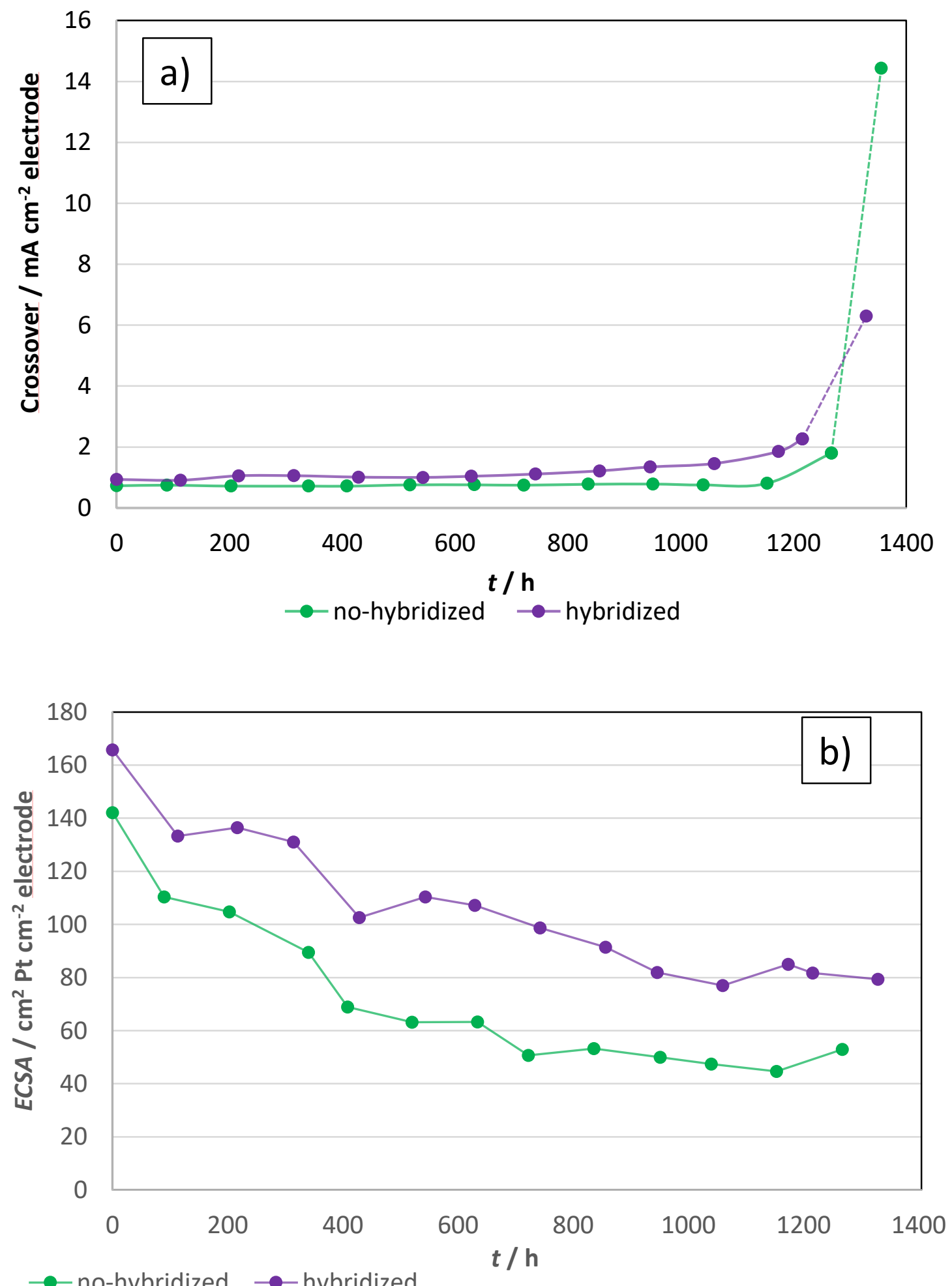

Figure 9: Aging of the cell under FC-DLC cycling depending on the hybridization mode. a) Membrane permeability to hydrogen expressed as a current density. b) Electrochemical active surface (ECSA) of the catalyst. 


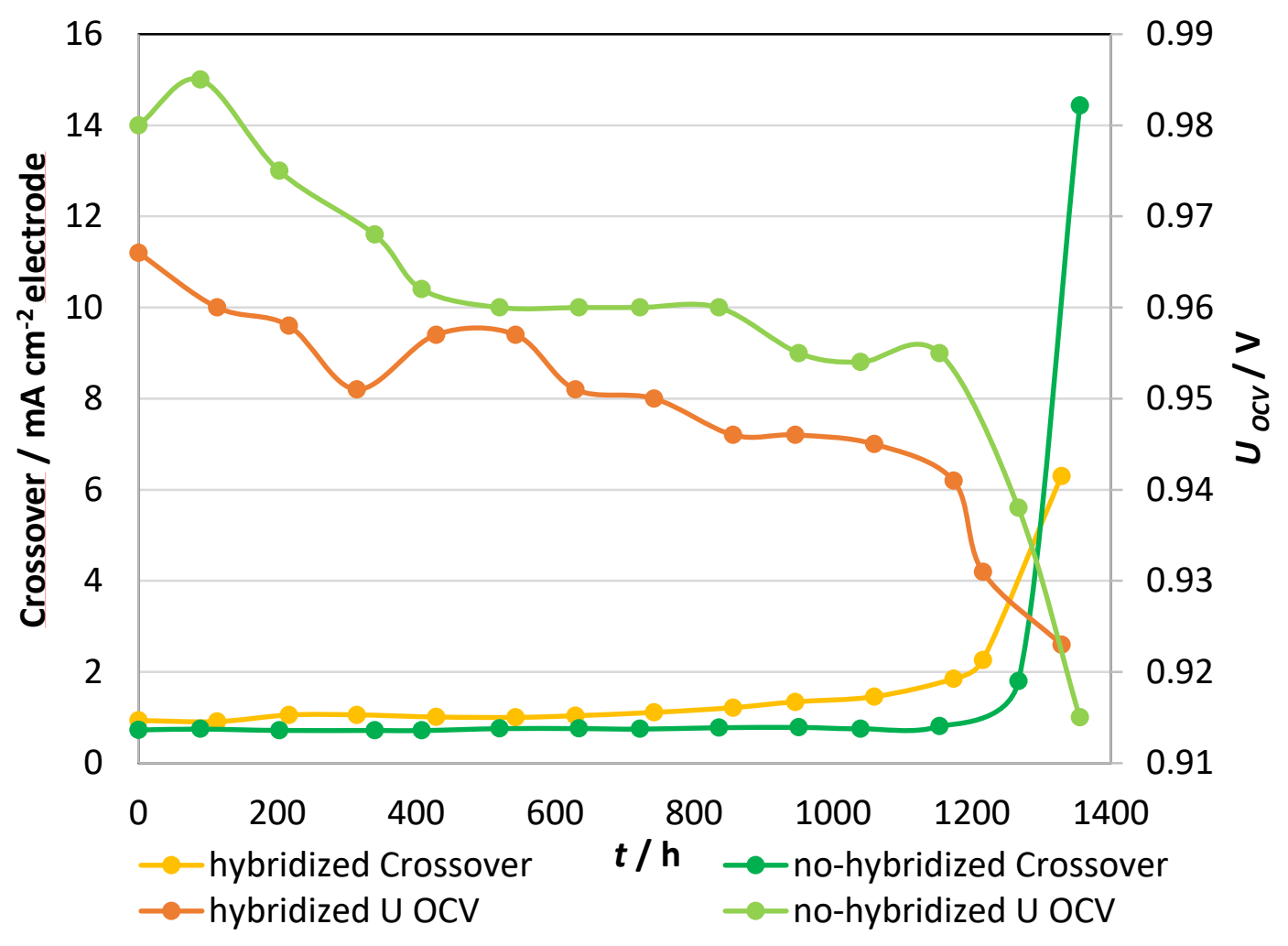

Figure 10: Hydrogen crossover and fuel cell OCV over time: simultaneous occurrence of sudden changes 


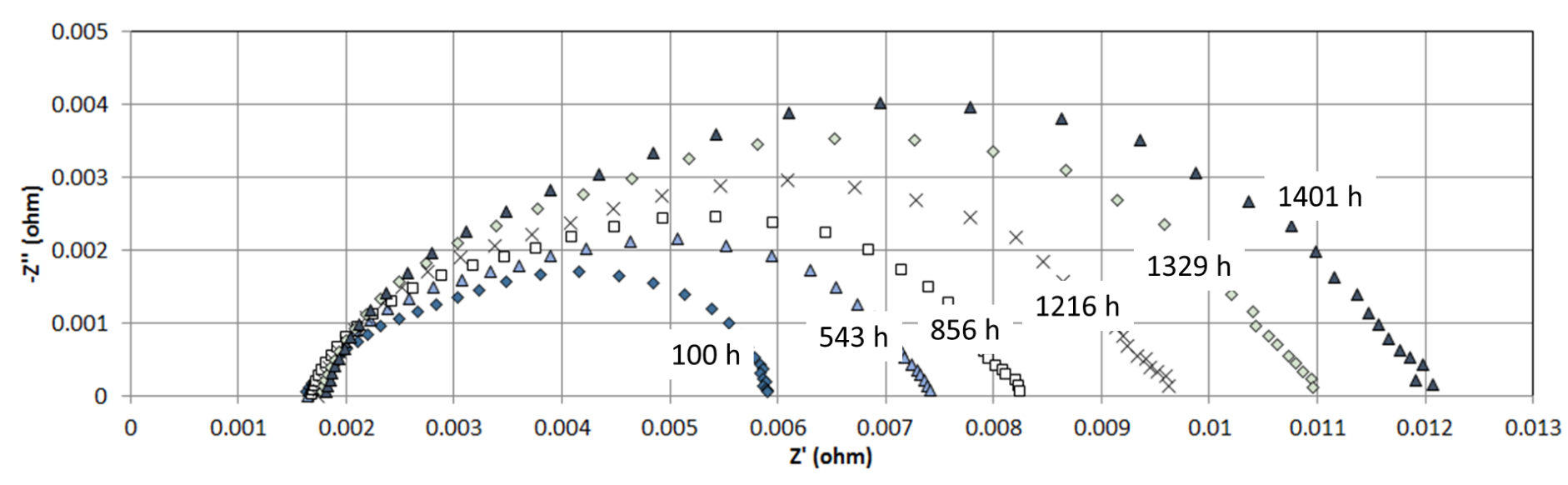

Figure 11: Examples of EIS recorded at $0.8 \mathrm{~A} \mathrm{~cm}^{-2}$ during the ageing run without $\mathrm{SC}$. 

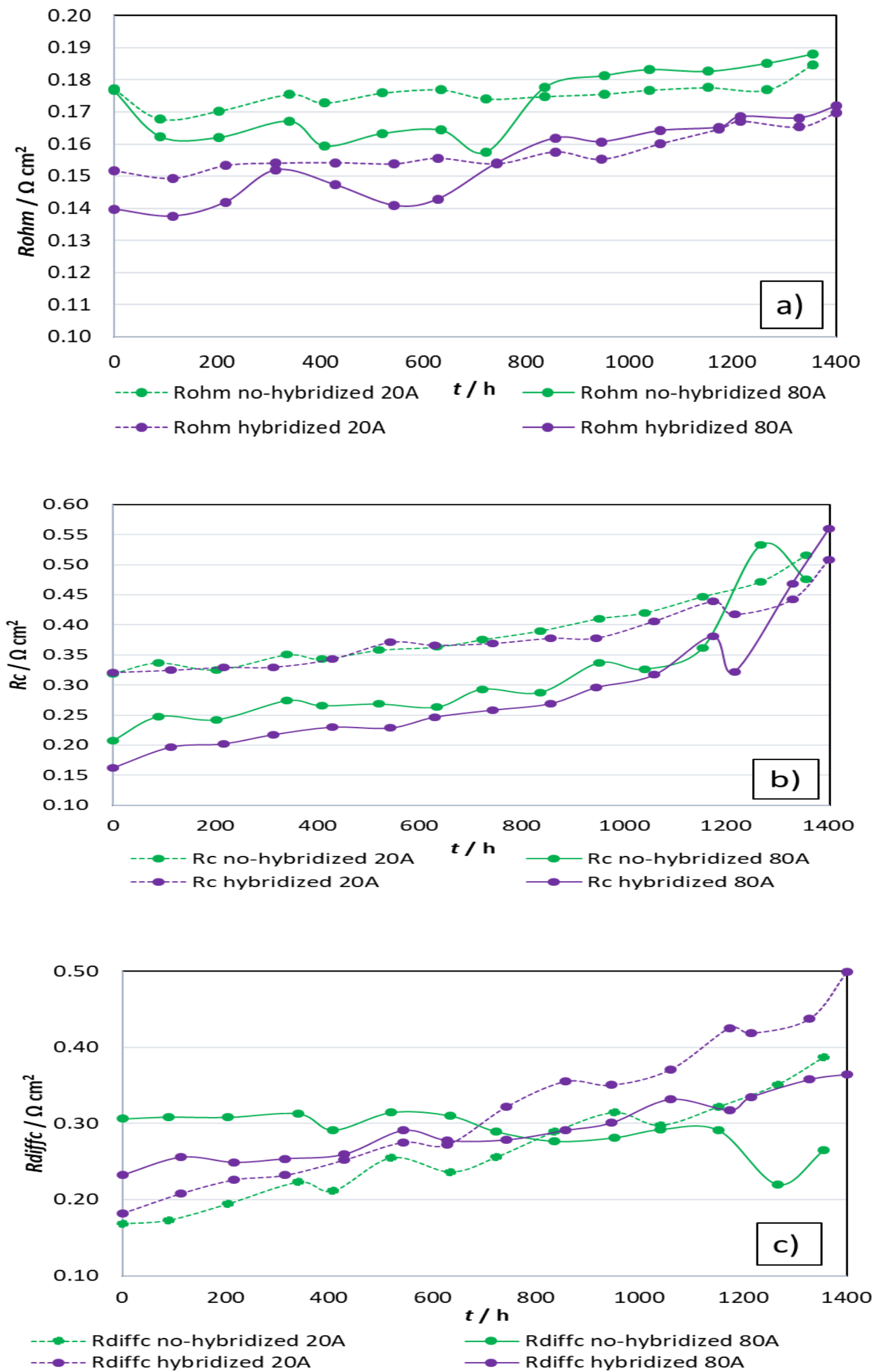


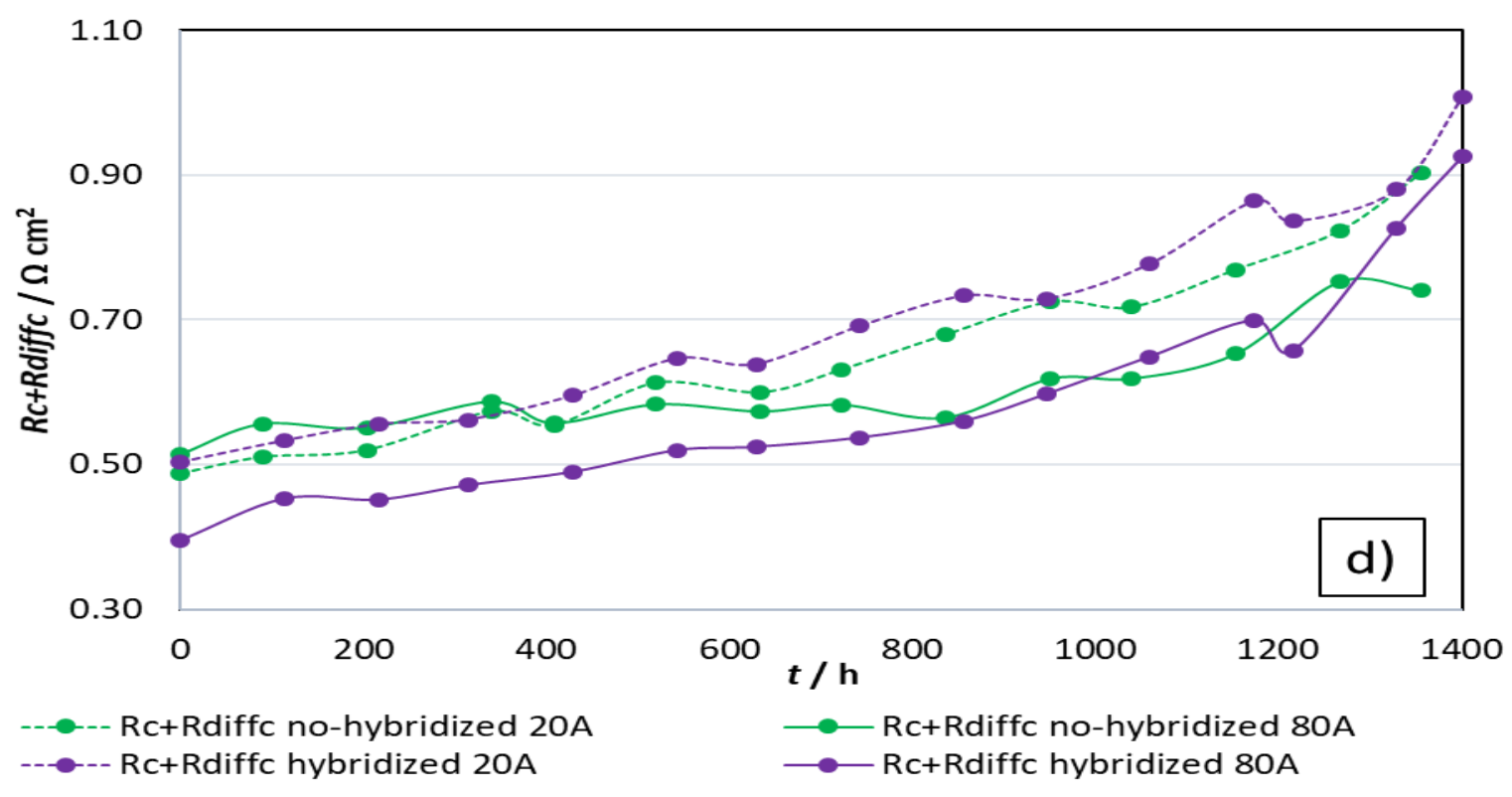

Figure 12 a) Ohmic resistance $\left(\mathrm{R}_{\mathrm{ohm}}\right)$. b) Charge transfer resistance at the cathode $\left(R_{c}\right)$. c) Diffusion resistance at the cathode $\left(\mathrm{R}_{\text {diff,c }}\right)$. $\left.d\right)$ Polarization resistance defined as $\left(R_{c}+R_{\text {diff,c }}\right)$. 


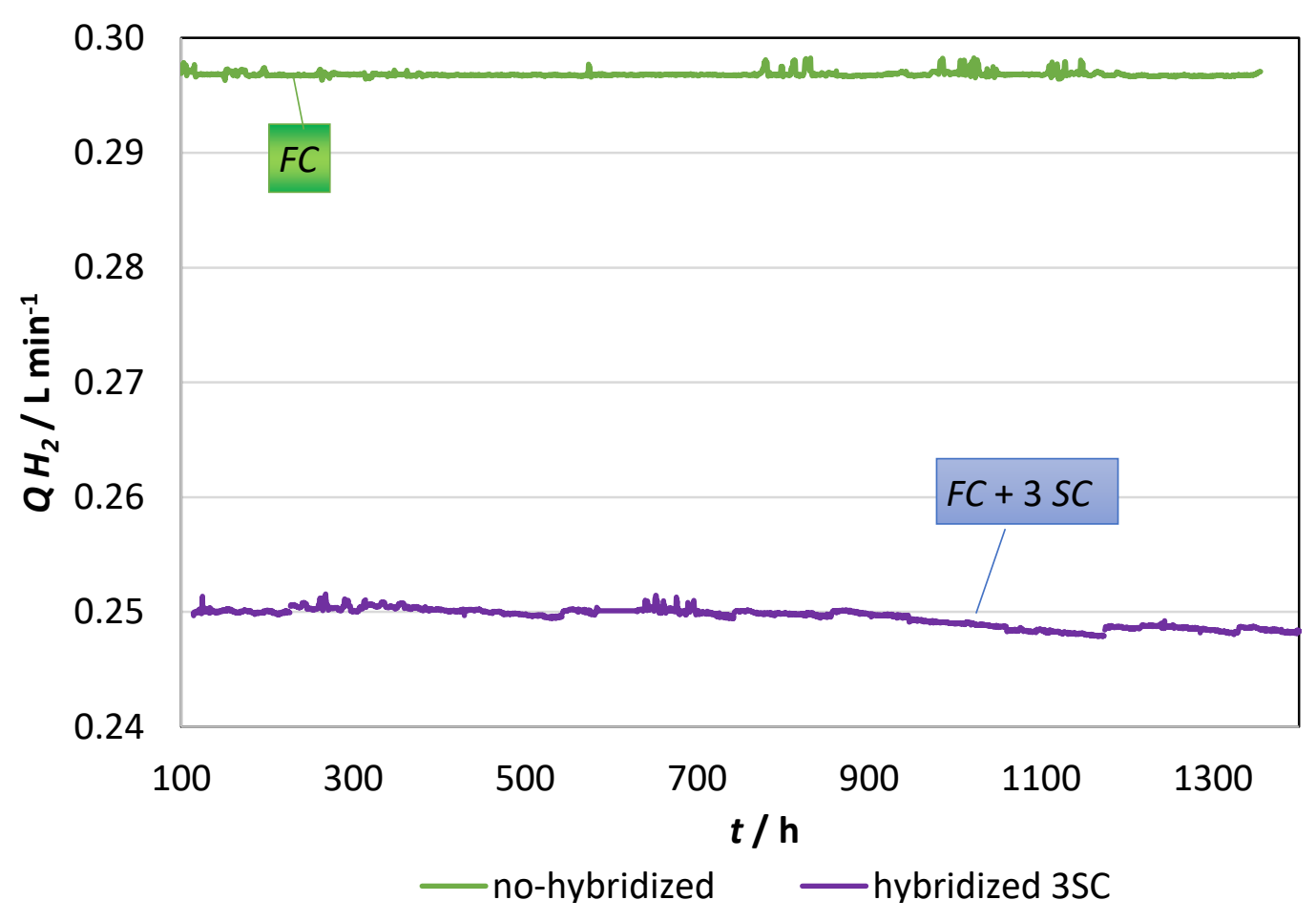

Figure 13: Average volume flow rate of hydrogen over time depending on the hybridization mode. 


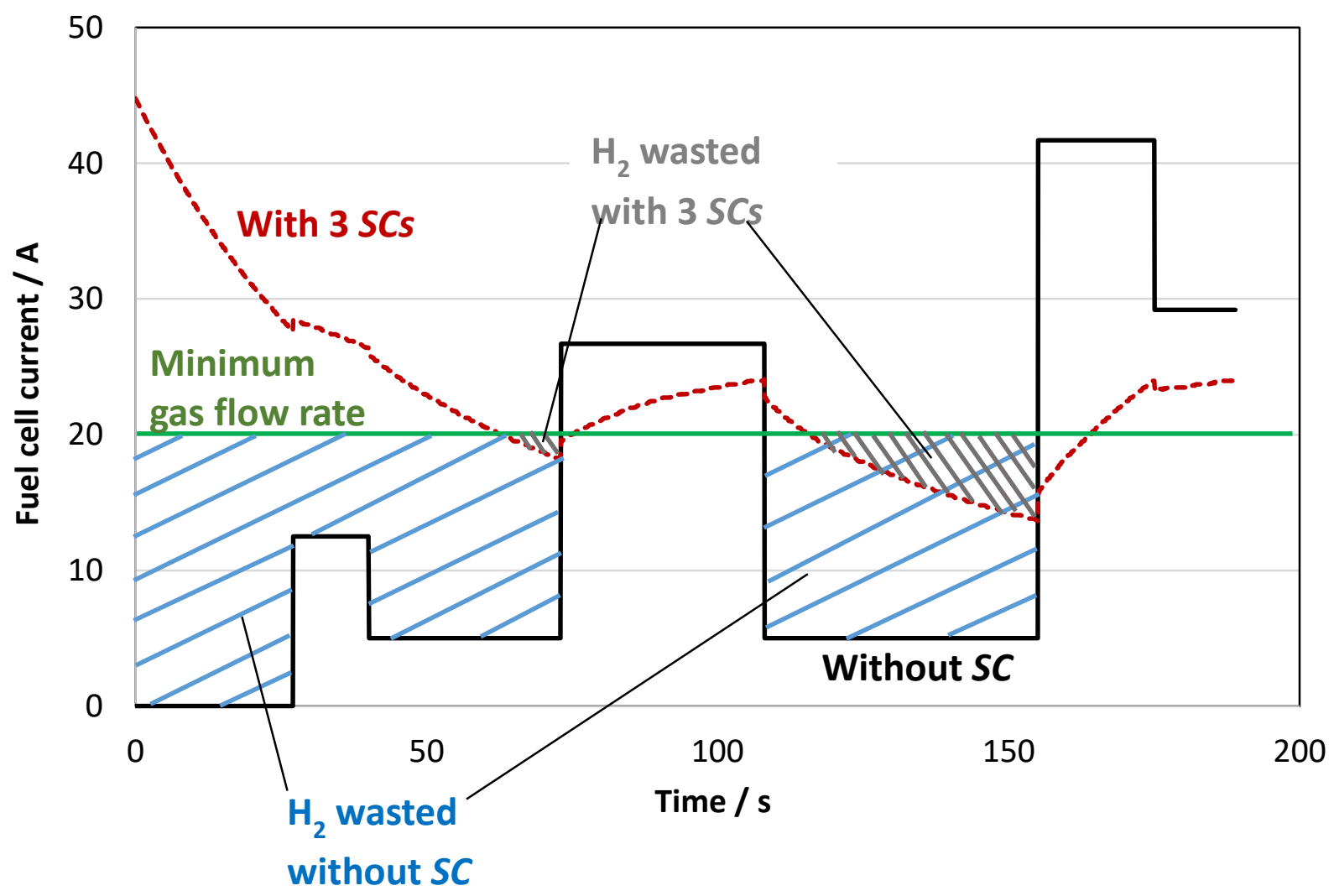

Figure 14: Zoomed view of the cell current IFC during FC-LDC cycle (after 300 hours) depending on the hybridization mode. The current corresponding to the minimum gas flow rate is also shown. The dashed areas are proportional to the amount of hydrogen lost in the operation, regardless of the $5 \mathrm{~s}$ time period between the changes in the flow rate set points and the positive current step. 